ORIGINAL ARTICLE

\title{
Diagnostic Patterns of Suspected Covid-19 Patients Using Scor Covid-19, PCR Test and Serological Test in Dr. Soetomo Hospital Surabaya, Indonesia
}

\author{
Usman Hadi $^{*}$ (D), Bramantono', M Vitanata1, Musofa Rusli1 ${ }^{(D)}$, Brian Eka Rahman ${ }^{1,2}$ \\ Tripudi Asmarawati ${ }^{1,2}$, Erika Marfiani, ${ }^{1,2}$ Erwin Astha Triyono ${ }^{1}$ \\ ${ }^{1}$ Department of Internal Medicine, Faculty of Medicine - Dr. Soetomo General Academic Hospital, Surabaya, Indonesia \\ ${ }^{2}$ Universitas Airlangga Hospital, Surabaya, Indonesia
}

\begin{abstract}
A B S T RA C T
Introduction: To find out the diagnostic pattern of COVID-19 using RT-PCR or a rapid antibody test in the suspected group patients.

Methods: The study was conducted in Dr. Soetomo General Hospital (referal hospital for covid-19, 1500 beds). The study used data on patients with suspected covid-19 who were hospitalized at the Dr. Soetomo General Hospital in Surabaya.

Results: There were 200 suspected COVID-19 patients enrolled in this study, the main complaints of cough, fever, dyspnoea, around 69.5\%, $75 \%$, and $76.5 \%$, respectively. Although not a common symptom, it seems that anosmia (14\%) is typical for COVID-19. Based on this scoring system, a total of 196 patients had a high risk of being infected with COVID-19, and 125 (64\%) of them finally showed a positive PCR test. PCR test mostly positive (62.5\%), while serological test (rapid imunoglobulin test) mostly non reactive, but there were nonsignificant different between PCR and Serological test ( $\mathrm{p}=0.16$ OR: $1.5(0.84-71)$. Furthermore, if we compare the various existing variables, namely the covid-19 score, immunoglobulin rapid test, and radiological examination, only the radiological examination results can be used as a strong predictor of positive PCR results $(\mathrm{p}=0.005$, OR: $1.68(0.17-16.43)$. In this study, we found that abnormal chest radiographs are a good parameter for diagnosing COVID-19, (OR: 2.92; $95 \%$ CI, $1.34-6.34)$.

Conclusion: The initial radiological examination combined with the clinical symptoms of Covid-19 is the most important thing to predict the presence of this disease.
\end{abstract}

Keywords: Covid-19, Immunoglobulin rapid test, Anosmia, Indonesia

Correspondence: Usman Hadi

E-mail: usman.hadi2@fk.unair.ac.id

Article history: •Received 10 December $2020 \bullet$ Received in revised form 29 January $2021 \bullet$ Accepted 5 February 2021

\section{INTRODUCTION}

Corona virus disease -19 (COVID-19) was identified in January 2019 in the city of Wuhan, China. This disease is caused by SARS-CoV-2. This virus is very contagious, spreading in all over the world and become pandemic in 20 March 2020 (WHO-A, 2020).

This disease mainly affects the respiratory system, although it can affect other organ system, mostly around $80 \%$ symptoms resolve without treatment within five to seven days of symptom onset. However, about $20 \%$ of patients will develop serious disease most notably pneumonia, acute respiratory distress syndrome, sepsis or septic schock, thrombotic stroke and myocardial infarction (WHO-A, 2020; Salehi et al., 2020; Huang et al., 2020; Yang et al., 2020).

To establish a definite diagnosis using real-time PCR using nasal and throat swab. While using serology rapid test for diagnosis COVID-19, the accuracy is only $30 \%$ up to $70 \%$ after the second week.
Antibody rapid test especially is used for epidemiological purposes. Clinical sign or symptoms and serological examination or radiological examination can be used to make a presumptive diagnosis, in areas that do not have PCR facilities (WHO-B, 2020).

The morbidity and mortality rates in Indonesia are still quite high. Currently, there are more than 580000 cases, with the death of more than 15000 patients. Therefore it is necessary to do further research to find out the diagnostic pattern of COVID-19 using RT-PCR or a rapid antibody test in the suspected group patients.

This study aims to determine the diagnostic pattern of COVID 19 at Dr. Soetomo Academic General Hospital Surabaya, the difference between the use of RT-PCR and rapid test in the suspected group, in Dr. Soetomo Hospital Surabaya. So that in the end the detection of COVID 19 cases can be mapped for use of RT-PCR or with an appropriate antibody rapid test or radiological examination. 


\section{METHODS}

Population and health care setting

The study was conducted in Dr. Soetomo General Hospital (referal hospital for covid-19, 1500 beds). The study used data on patients with suspected covid-19 who were hospitalized at the Dr. Soetomo General Hospital in Surabaya from April 2020 to June 2020 in accordance with the inclusion and exclusion criteria.

Study design and inclusion procedure.

Inclusion Criteria

Suspected Covid-19 patients who were hospitalized at the Dr. Soetomo General Hospital in Surabaya from April 2020 to June 2020.

\section{Exclusion Criteria}

Suspected Covid-19 patients with incomplete data, namely no date of admission to the hospital, and incomplete records, especially the diagnosis.

Prosedure of the research

The study was conducted by looking back at the medical records of Covid-19 patients who were hospitalized at the isolation room. Demographic data, subject characteristic, and underlying comorbidities, symptoms and signs at presentation, value of Covid-19 score, also complication and outcome were colected and evaluated.

Rreal time polymerase chain reaction (RT-PCR) testing was performed for confirmation of SARS-CoV-2, and laboratory test of SARS-CoV-2 IgM/IgG was also performed for all patients. A chest radiograph were obtained at baseline and as determined clinically by heatlh care practitioners on case by case basis.

\section{RESULTS}

Characteristics of research subjects

There were 200 suspected COVID-19 patients enrolled in this study in dr Soetomo General Hospital. All patients underwent rapid antibody test, RT-PCR, laboratory, and imaging examination during treatment. The patient is stratified using a scoring system to assess the risk of being infected with COVID-19. Based on this scoring system, a total of 196 patients had a high risk of being infected with COVID-19, and 125 (64\%) of them finally showed a positive PCR test.

Most patients presented with complaints, the main complaints of cough, fever, dyspnoea, around 69.5\%, 75\%, and $76.5 \%$, respectively. Although not a common symptom, it seems that anosmia (14\%) is typical for COVID-19.

PCR test mostly positive (62.5\%), while serological test (rapid immunoglobulin test) mostly non reactive, but there were nonsignificant different between PCR and Serological test ( $\mathrm{p}=0.16$ OR: $1.5(0.84-71)$.

Table 1 Characteristic Patients

\begin{tabular}{|c|c|}
\hline $\begin{array}{l}\text { Demographic } \\
\text { Characteristic }\end{array}$ & $\begin{array}{c}\text { Dr. Soetomo Hospital N(\%) } \\
\text { (200 patients) }\end{array}$ \\
\hline Age, mean (SD), y & $51.2(14.1)$ years \\
\hline Age $>60 y$ & $55(27.5)$ \\
\hline Female & $85(42.5)$ \\
\hline Cough & $139(69.5)$ \\
\hline Nasal congestion & $60(30)$ \\
\hline Dyspnea & $150(75)$ \\
\hline Fever & $153(76.5)$ \\
\hline Anosmia & $29(14)$ \\
\hline Diarrhea & $39(19.5)$ \\
\hline Nausea or vomiting & $61(30.5)$ \\
\hline Abdominal pain & $33(16.5)$ \\
\hline Comorbid conditions & Dr. Soetomo Hospital N(\%) \\
\hline Diabetes mellitus & $82(41.0)$ \\
\hline Hypertension & $74(37.0$ \\
\hline Chronic kidney disease & $60(30)$ \\
\hline Obesitas & $3(1.5)$ \\
\hline Malignancy & $19(9.5)$ \\
\hline Autoimmun diseases & $7(3.5)$ \\
\hline Heart disease & $15(7.5)$ \\
\hline HIV & $3(1.5)$ \\
\hline Scoring at admission & Dr. Soetomo Hospital N(\%) \\
\hline $5-8$ & $4(2)$ \\
\hline $9>$ & $196(98)$ \\
\hline $\begin{array}{c}\text { Prior hospitalization } \\
\text { symptoms }\end{array}$ & Dr. Soetomo Hospital N(\%) \\
\hline $2-3$ days & $37(18.5)$ \\
\hline $4-7$ days & $131(65.5)$ \\
\hline 8-14 days & $32(16)$ \\
\hline
\end{tabular}

Table 2 Diagnostic Laboratory

\begin{tabular}{lcc}
\hline & $\begin{array}{c}\text { Positive or } \\
\text { reactive: } \\
\mathrm{N}(\%)\end{array}$ & $\begin{array}{c}\text { Negative or } \\
\text { non } \\
\text { reactive: } \mathrm{N}(\%)\end{array}$ \\
\hline PCR & $125(62.5)$ & $75(37.5)$ \\
\hline $\begin{array}{l}\text { Rapid } \\
\text { imunoglobulin } \\
\text { test (IgM/IgG) }\end{array}$ & $90(45)$ & $110(55)$ \\
\hline
\end{tabular}

Furthermore, if we compare the various existing variables, namely the covid-19 score, immunoglobulin rapid test, and radiological examination, only the radiological examination results can be used as a strong predictor of positive PCR results ( $\mathrm{p}=0.005$, OR: 1.68 (0.17-16.43).

Table 3 Comparison between Serological, scor Covid-19, and Chest X-ray Result with PCR Test on Admission

\begin{tabular}{|c|c|c|c|}
\hline & $\operatorname{PCR}(-)$ & $\mathrm{PCR}(+)$ & Chi-Square test \\
\hline IgG/M: non reactive & 46 & 64 & $p=0.106$ \\
\hline IgG/M: reactive & 29 & 61 & OR: $1.5(0.84-71)$ \\
\hline Scor: $5-8$ & 2 & 73 & $\mathrm{p}=0.482$ \\
\hline Scor: $9>$ & 2 & 123 & OR: $1.68(0.17-16.43)$ \\
\hline Chest $\mathrm{X}$ rays: normal & 19 & 56 & $\mathrm{p}=0.005$ \\
\hline Chest $\mathrm{X}$ rays: infiltrat + & 13 & 112 & OR: $2.92(1.34-6.34)$ \\
\hline
\end{tabular}

In this study, we found $65.5 \%$ of the final confirmatory diagnosis of Covid-19, this shows that there is still a possibility that non-Covid-19 (discharded) sufferers will 
enter initial care as Covid-19.

Table 4 Final Diagnosis on Discharge

\begin{tabular}{lc}
\hline \multicolumn{1}{c}{ Final Diagnosis } & Dr. Soetomo N(\%) \\
\hline Suspected Covid-19 & $46(23)$ \\
\hline Probable Covid-19 & $29(14.5)$ \\
\hline Confirmed Covid-19 & $125(62.5)$ \\
\hline
\end{tabular}

\section{DISCUSSION}

To control the impact of its spread, early detection procedures are needed. WHO recommends RT-PCR examination as the gold standard for examining COVID-19, because as a developing country the fulfillment of these facilities cannot be achieved ideally. Therefore, a rapid antibody test that can be widely used is needed, does not require special facilities and is cheap to help detect COVID19. A study reported that the antibody rapid test sensitivity and specificity were $64.8 \%$ and $98 \%$, respectively (Ricco et al., 2020). Supports another study that divided the rapid test according to its working principle, which reported a combined sensitivity for LFIA of $66 \%$ (95\% CI 49.3-79.3), and a combined specificity of $96.6 \%-99.7 \%$ (Bastos et al., 2020). In this study, the sensitivity obtained was only $55.28 \%$ and the specificity was much lower, namely $60.38 \%$. These results are due to patients presenting for treatment varying in duration of symptoms from onset.

In this study, we found that abnormal chest radiographs are a good parameter for diagnosing COVID-19, (OR: 2.92; $95 \%$ CI, $1.34-6.34)$. This finding is in line with previous studies that indicated chest radiographs were stated in COVID-19 patients often show bilateral lower zone consolidation, which peaks in 10-12 days from the onset of the disease (Wong et al., 2020). Another report showed that chest radiograph had a sensitivity of $89.0 \%$ (95\% confidence interval (CI), $85.5 \%-91.8 \%$ ), a specificity of $60.6 \%$ (95\% CI, $51.6 \%-69.2 \%), 87.9 \%$ positive predictive value (95\% CI, $84.4 \%-90.9 \%$ ), and a negative predictive value of $63.1 \%$ (95\% CI, 53.9\%-71.7\%). These results indicate that the CXR examination together with RT-PCR for triage of suspected COVID-19 patients can provide a safe and efficient workflow (Salehi et al., 2020; Schiaffino et al., 2020; Shi et al., 2020).

A scoring system for COVID-19 triage is established in our hospital based on the latest reports on the risk factors, signs and symptoms of patients with COVID-19. This system is created to determine the need for isolation protocols. This study is the first study to evaluate the performance of our scoring system. The results showed that the scoring system was not correlated with the PCR test. A scoring system for COVID-19 triage is essential for alerting health workers and implementing the necessary protocols to prevent disease transmission. Several researchers developed an early warning system to identify highly suspicious COVID-19 patients during surgical planning. Based on literature search, the risk factors for COVID-19 are as follows: history of exposure, fever, cough, and radiographic infiltrates (Greenhalgh et al.,2020; Jacobi et al., 2020; Aljondi et al., 2020; Bhaskar et al., 2020). The components in this scoring system are relatively similar to our in-hospital scoring system, although the higher scores do not reflect a higher probability of COVID-19 confirmation. These results may be due to the limited sample size of our study, and we only included suspects or confirmed COVID-19 patients admitted to internal medicine isolation wards, so there would be patient selection bias.

\section{CONCLUSION}

Examining COVID-19, according to WHO standards, is still a challenge for developing countries such as Indonesia. The workload of the RT-PCR examination laboratory leads to a longer waiting period for examination results. On the other hand, the shortest possible diagnostic time is the key to controlling a pandemic. The initial radiological examination combined with the clinical symptoms of Covid-19 is the most important thing to predict the presence of this disease.

\section{ACKNOWLEDGEMENT}

Universitas Airlangga grant supported this research. The authors wish to thank all enrolled patients and healthcare workers, especially Eric Wibisono, Miftahani Leo Choirunnisa, Dwi Retno Puji Rahayu, and Bagus Aulia Mahdi, for their kind contribution in collecting data.

\section{CONFLICT OF INTEREST}

The authors declare there is no conflict of interest.

\section{REFERENCES}

Aljondi R, Alghamdi S. 2020. Diagnostic value of imaging modalities for COVID-19: scoping review. J Med Internet Res 22:e19673. doi:10.2196/19673.

Bastos ML, Tavaziva G, Abidi SK, Campbell JR, Haraoui LP, Johnston JC, Lan Z, Law S, MacLean E, Trajman A, Menzies D, Benedetti A, Khan FA. 2020. Diagnostic accuracy of serological tests for covid-19: systematic review and meta-analysis. BMJ 2020:m2516. doi:10.1136/ bmj.m2516.

Bhaskar S, Ali Z, Goneppanavar U, Dongare P, Garg R, Kannan S, Harsoor S. 2020. Development of a preoperative early warning scoring system to identify highly suspect COVID-19 patients. J Anaesthesiol Clin Pharmacol 36: 62.doi:10.4103/joacp.joacp_274_20.

Greenhalgh T, Thompson P, Weiringa S, Neves AL, Husain L, Dunlop M, Rushforth A, Nunan D, de Lusignan S, Delaney B. 2020. What items should be included in an early warning score for remote assessment of suspected 
COVID-19? qualitative and Delphi study. BMJ Open 10: e042626. doi:10.1136/bmjopen-2020-042626.

Huang C, Wang Y, Li X, Ren L, Zhao J, Hu Y, et al. 2020.

Clinical features of patients infected with 2019 novel coronavirus in Wuhan, China. Lancet 395(10223):497-495.

Jacobi A, Chung M, Bernheim A, Eber C. 2020. Portable chest X-ray in coronavirus disease-19 (COVID-19): a pictorial review. Clin Imaging 64:35-42. doi:10.1016/ j.clinimag.2020.04.001.

Riccò M, Ferraro P, Gualerzi G, Ranzieri S, Henry BM, Said YB, Pyatigorskaya NV, Nevolina E, Wu J, Bragazzi NL, Signorelli C. 2020. Point-of-care diagnostic tests for detecting SARS-CoV-2 antibodies: a systematic review and meta-analysis of real-world data. J Clin Med 9:1515. doi:10.3390/jcm9051515.

Salehi S, Abedi A, Balakrishnan S, Gholamrezanezhad A. 2020. Coronavirus Disease 2019 (COVID-19): A Systematic Review of Imaging Findings in 919 Patients. AJR Am J Roentgenol 2020:1-7.

Schiaffino S, Tritella S, Cozzi A, Carriero S, Blandi L, Ferraris L, Sardanelli F. 2020. Diagnostic performance of chest X-Ray for COVID-19 pneumonia during the SARSCoV-2 pandemic in Lombardy, Italy. J Thorac Imaging 2020,
35, W105-W106. doi:10.1097/rti.0000000000000533.

Shi H, Han X, Jiang N, Cao Y, Alwalid O, Gu J, et al. 2020. Radiological findings from 81 patients with COVID-19 pneumonia in Wuhan, China: a descriptive study. Lancet Infect Dis 2020.

Wong HYF, Lam HYS, Fong AHT, Leung ST, Chin TWY, Lo CSY, Lui MMS, Lee JCY, Chiu KWH, Chung T, et al. 2020. Frequency and distribution of chest radiographic findings in COVID-19 positive patients. Radiology 2020, p201160.

World Health Organization (WHO-A). 2020. Clinical management of severe acute respiratory infection (SARI) when Covid-19 disease is suspected: interim guidence. Accessed 13 March 2020.

World Health Organization (WHO-B). 2020. Laboratory testing for coronavirus disease 2019 (COVID-19) in suspected human cases. Geneva: World Health Organization.

Yang X, Yu Y, Xu J, Shu H, Xia J, Liu H, et al. 2020. Clinical course and outcomes of critically ill patients with SARS-CoV-2 pneumonia in Wuhan, China: a singlecentered, retrospective, observational study. Lancet Respir Med. DOI: 10.13140/RG.2.2.28124.74882. 